\title{
Guns and Butter - But No Margarine: The Impact of Nazi Economic Policies on German Food Consumption, 1933-38
}

\author{
By Mark Spoerer (Regensburg) and Jochen Streb (Mannheim)
}

\section{Introduction}

In the second half of the 1930s Germany experienced high economic growth rates and a rapid decline of unemployment that was unparalleled in Europe. Contemporary observers, both inside and outside of Germany, believed they were witnessing a Wirtschaftswunder (economic miracle). ${ }^{1}$ Even after the defeat of the Nazi regime, Germany's economic policy continued to receive attention. At a time when Keynesian ideas began dominating economic policy makers' thinking the apparent success of the Nazis' interventionist policies between 1933 and 1939 was seen as a case study which might serve as a possible model for democratic planners, and therefore something worthy of detailed attention. ${ }^{2}$

It soon became clear that Nazi economic policy had little, if anything at all, to offer democratic policy makers. Yet the assessment of its success has remained controversial. Some scholars have agreed with the Swiss economist René Erbe's sceptical judgement that the economic upturn was accompanied by a reallocation of resources from the production of consumer goods to the production of armaments and was financed by enormous debts. ${ }^{3}$

This view, which is by and large shared by most economic historians of Nazi Germany today, has proved to be difficult to reconcile with the fact that a clear majority of the German population were in support of the new regime. ${ }^{4}$ One argument that has been repeated ever since and which contemporary witnesses even today reiterate is that the improved provision of material goods contributed to this positive assessment of a murderous regime. This contention found authoritative support from a study of the American economist Burton Klein, who had served for the United States Strategic Bombing Survey under John K. Galbraith in the mid-1940s. In his analysis of the 1930s German rearmament program he concluded that:

'in the prewar period, the German economy produced both 'butter' and 'guns'

- much more of the former and much less of the latter than has been commonly

1 Cf. H.E. Priester, Das deutsche Wirtschaftswunder, Amsterdam 1936; W. Prion, Das deutsche Finanzwunder. Geldbeschaffung für den deutschen Wirtschaftsaufschwung, Berlin-Willmersdorf 1938; C.W. Guillebaud, The Economic Recovery of Germany from 1933 to the Incorporation of Austria in March 1938, London 1939.

2 Cf., e.g., Guillebaud, Economic Recovery, pp. 232-233, 265; O. Nathan/M. Fried, The Nazi Economic System. Germany's Mobilization for War, Durham 1944, pp. vi, 368; S. Lurié, Private Investment in a Controlled Economy. Germany, 1933-1939, New York 1947, p. vii. Cf. also W.C. Haraldson/E.F. Denison, The Gross National Product of Germany 1936-1944, Washington, DC 1946; B. Klein, Germany's Economic Preparations for War, Cambridge, Mass. 1958, p. v.

3 Cf. R. Erbe, Die nationalsozialistische Wirtschaftspolitik im Lichte der modernen Theorie, Zurich 1958. For a revisionist view concerning Germany's indebtedness, see A. Ritschl, Deficit Spending in the Nazi Recovery: A Critical Reassessment, in: Journal of the Japanese and International Economy 16, 2002, pp. 559-582.

4 For quantitative evidence cf:: $K .-H$. Reuband, Das NS-Regime zwischen Akzeptanz und Ablehnung. Eine retrospektive Analyse von Bevölkerungseinstellungen im Dritten Reich auf der Basis von Umfragedaten, in: GG 32, 2006, pp. 315-343. 
assumed. By 1937, civilian consumption, investment in consumer goods industries, and government nonwar expenditures equalled or exceeded previous peak levels. [...] Until 1936, rearmament and increased civilian consumption could be achieved simultaneously by drawing on unemployed resources. Indeed, the rearmament deficits had a stimulating effect on consumption. There was no conflict, therefore, in having both more 'butter' and more 'guns'. In the years 1937 and 1938, however, the German economy was operating at near full employment, and a sizable increase in armament expenditures could have been achieved only at the expense of some decline in civilian consumption. [...] It appears, however, that the German government was unwilling to ask for such sacrifices." 5

The findings of subsequent research on German agriculture have been in line with this assessment. The main subject of this research was the Reichsnährstand (Reich Food Corporation) founded by the Nazis in 1933, which was in charge of regulating German agricultural production and distribution and which soon started a much propagated Erzeugungsschlacht (battle for production). Both John Farquharson and in particular Clifford R. Lovin argued that the Nazi agricultural policies were successful in augmenting food production and increasing national self-sufficiency. ${ }^{6}$

These findings were taken up eagerly by historians when it came to a reassessment of the Nazi period in the course of the 'modernisation' debate. At the core of the discussion was the question whether the Nazi regime was modern in the sense that in many respects it did not deviate from wider 20th century trends. In this context, a number of German historians in the 1980s emphasised that the standard of living increased considerably over the course of the 1930s. ${ }^{7}$ In a leading text book on the period, the historian Hans-Ulrich Thamer argues that the reduction of unemployment and the enhancement of the living standard were among "the assets of the economic and social policies of the regime". 8

This positive assessment of Nazi agricultural and consumption policies has recently found support fromy Werner Abelshauser and, in particular, Götz Aly. While Abelshauser is careful enough to note that "the German diet was remarkably modest", his provocative conclusion that the Nazis were "largely successful" in producing both "butter and guns" has evoked objections. ${ }^{9}$

5 Klein, Economic Preparations pp. 76, 79.

6 Cf. C.R. Lovin, Agricultural Reorganization in the Third Reich. The Reich Food Corporation (Reichsnährstand), in: Agricultural History 43, 1969, pp. 447-461; J. E. Farquharson, The Plough and the Swastika. The NSDAP and Agriculture in Germany 1928-45, London 1976, pp. 176-177.

7 Cf. H.D. Schäfer, Das gespaltene Bewußtsein. Über deutsche Kultur und Lebenswirklichkeit 1933-1945, Munich 1981, pp. 116-119; M. Prinz, Vom neuen Mittelstand zum Volksgenossen. Die Entwicklung des sozialen Status der Angestellten von der Weimarer Republik bis zum Ende der NS-Zeit, Munich 1986, pp. 187-196; Idem, Die soziale Funktion moderner Elemente in der Gesellschaftspolitik des Nationalsozialismus, in: Idem/R. Zitelmann (Eds.), Nationalsozialismus und Modernisierung, Darmstadt ${ }^{2} 1994$, pp. $297-$ 327, here pp. 316-317.

8 Our translation from H.-U. Thamer, Verführung und Gewalt. Deutschland 1933-1945, Berlin ${ }^{3} 1998$, p. 511 (first edition 1986).

9 Cf. W. Abelshauser, Germany: Guns, Butter, and Economic Miracles, in: M. Harrison (Ed.), The Economics of World War II. Six Great Powers in International Comparison, Cambridge 1998, pp. 122176, quotes pp. 147-148; Idem, Kriegswirtschaft und Wirtschaftswunder. Deutschlands wirtschaftliche 
Following in the footsteps of Erbe, Christoph Buchheim has termed the Nazi economic upturn "distorted growth". ${ }^{10}$ The discussion between Abelshauser and Buchheim illustrates a crucial problem in assessing the performance of Nazi economic policies, which also occurs in other comparative work on this period. While Abelshauser compares the standard of living in the late 1930s with that of the trough of the crisis years, 1932 (as did Nazi propaganda, official German statisticians and probably the common consumers of the 1930s as well), Buchheim's reference period is the late 1920s when Germany's economy experienced a short - though financed by massive foreign debt inflow - economic boom. Thus his assessment of the material living standard in the second half of the 1930s is much more critical than Abelshauser's.

Buchheim's stance is supported by the results of Jörg Baten and Andrea Wagner who have supplied evidence from social and medical data. Whereas the biological standard of living improved in Western European countries during the 1930s, it stagnated in Germany. ${ }^{11}$ In addition, research on German agriculture has contradicted Lovin and Farquharson's positive assessments. By comparing agricultural output and input of the 1930s with that of the first third of the 20th century, Gustavo Corni argued that the path of modernisation slowed down in the 1930s. ${ }^{12}$ This result has been confirmed by a total factor productivity (TFP) analysis undertaken by Stephanie Degler and Jochen Streb, who found that the TFP growth of German agriculture slowed down significantly in the 1930s, compared to the 1920 s and the 1950 s. ${ }^{13}$

Yet the latest contribution to the debate on the effects of Nazi economic and consumption policies on welfare carries the revisionist view to extremes. In an influential book, the historian Götz Aly argues that the Nazi regime bribed ordinary Germans by redistributing wealth taxed from the German rich and looted from the peoples in the occupied territories and from European Jewry. His main argument, the securing of political consent by redistribution, is expressed in the book's title, Hitlers Volksstaat (Hitler's people's state). ${ }^{14}$ While Aly's economic arguments were heavily criticised by Adam Tooze and Mark Spoerer, ${ }^{15}$ his success in the public debate - the book was widely discussed in the media and saw its fifth edition two months after initial publication - demonstrates the relevance of the issue.

Mobilisierung für den Zweiten Weltkrieg und die Folgen für die Nachkriegszeit, in: VfZ 47, 1999, pp. 503538 , here p. 525.

10 Cf. C. Buchheim, Die Wirtschaftsentwicklung im Dritten Reich - mehr Desaster als Wunder. Eine Erwiderung auf W. Abelshauser, in: VfZ 49, 2001, pp. 653-664. Cf. also M. Spoerer, Demontage eines Mythos? Zu der Kontroverse über das nationalsozialistische "Wirtschaftswunder", in: GG 31, 2005, pp. 415-438.

11 Cf. J. Baten/A. Wagner, Autarchy, Market Disintegration, and Health. The Mortality and Nutritional Crisis in Nazi Germany, 1933-1937, in: Economics and Human Biology 1, 2003, pp. 1-28.

12 Cf. G. Corni, Hitler and the Peasants. Agrarian Policy in the Third Reich, 1930-1939, New York 1990, p. 174.

13 Cf. S. Degler/J. Streb, Die verlorene Erzeugungsschlacht. Die nationalsozialistische Landwirtschaft im Systemvergleich, in: JWG 2007/2, pp. 161-181. Cf. also J. Streb/W. Pyta, Von der Bodenproduktivität zur Arbeitsproduktivität. Der agrarökonomische Paradigmenwechsel im Dritten Reich, in: Zeitschrift für Agrargeschichte und Agrarsoziologie 53, 2005, pp. 56-78.

14 Cf. G. Aly, Hitlers Volksstaat. Raub, Rassenkrieg und nationaler Sozialismus, Frankfurt a.M. 2005.

15 Cf. A. Tooze, Economics, Ideology and Cohesion in the Third Reich: A Critique of Götz Aly's "Hitlers Volksstaat", http://de.scribd.com/doc/4099126/toozealy, accessed 19 Oct. 2012; Review Spoerer on Aly, in: H-Soz-Kult, 26 May 2005, http://hsozkult.geschichte.hu-berlin.de/rezensionen/2005-2-143, accessed 19 Oct. 2012; cf. also C. Buchheim, Der Mythos vom "Wohlleben". Der Lebensstandard der deutschen Zivilbevölkerung im Zweiten Weltkrieg, in: VfZ 58, 2010, pp. 299-328. 
In this paper, we systematise the findings of different lines of recent research on the consumption of consumer goods and bring new evidence to light. While earlier research has focused on describing the policies that affected the production and consumption of consumer goods we assess the results. We focus our analysis on food products, as their quality deteriorated to a lesser extent in comparison to other consumer goods. We investigate how far the Nazis' policies affected actual food consumption, by taking the late 1920s and the 1950s as benchmark periods. In these two democratic periods, whilst certainly not free from state intervention, food consumption was influenced by interventionist government policies to a much lesser extent than in the 1930s.

As a result, we find that food consumption was affected much more starkly in the 1930s than hitherto thought. The diet German households consumed in the 1930s was much more frugal than the one consumed in the early 1950s, when GDP and disposable income were about the same, but when production was less regulated and consumption largely unconstrained. These findings, which pertain to most elementary issues at a time when typical worker households still had to devote 45 per cent of their income to buying food, leave little room for interpreting the Nazi period as 'modern' or 'social'.

\section{Nazi Policies Affecting Consumer Goods Consumption: An Overview}

It is now widely accepted that the Nazis headed for war straight after the takeover of power in January 1933. The prioritisation of armaments production was constrained by two factors which were closely interrelated. Firstly, at the beginning of the Third Reich, the regime's popularity was inseparably attached to its ability to reduce unemployment, ${ }^{16}$ which, including the hidden employment reserve, reached 7.6 million people (close to a quarter of the labour force) in the winter of $1932-33 .{ }^{17}$ Whilst this problem was overcome by 1936 when full employment was achieved, the second factor proved to be persistent and of increasing importance as the number of unemployed on the dole decreased. After several years of economic hardship, households wanted their consumption needs fulfilled. The regime's trade-off between vigorous rearmament and onerous consumer satisfaction led to a policy which has been termed by Abelshauser "as much butter as necessary, as many guns as possible". ${ }^{18}$

In this conflict between the consumption needs of private households on the one hand and those of the state on the other, one obvious measure was to encourage savings. The German state, however, was by far the largest debtor and was thus unwilling to increase the interest rate. Hence the only means of increasing household savings was moral suasion. However, it turned out that this was insufficient by a long way to absorb the increasing purchasing power. Despite massive propaganda, the savings-income ratio remained remarkably low from 1933

16 Cf. A. van Riel/A. Schram, Weimar Economic Decline, Nazi Economic Recovery, and the Stabilization of Political Dictatorship, in: Journal of Economic History 53, 1993, pp. 71-105.

17 Cf. C. Buchheim: Zur Natur des Wirtschaftsaufschwungs in der NS-Zeit, in: Zerrissene Zwischenkriegszeit. Wirtschaftshistorische Beiträge. Knut Borchardt zum 65. Geburtstag, Baden-Baden 1994, pp. 97-119, here p. 106; W.G Hoffmann et al., Das Wachstum der deutschen Wirtschaft seit der Mitte des 19. Jahrhunderts, Berlin 1965, p. 206.

18 Abelshauser, Germany, p. 131. 
to $1937 .{ }^{19}$ As a consequence, the German authorities increasingly relied on interventionist measures that were intended to satisfy the level of consumer needs that was seen as sufficient for sustaining political power, using as little resources as necessary.

Figures 1a and 1b illustrate these measures in a stylised way. The commodity in figure 1a is 'rationed' in the sense that the German authorities were unwilling to have it supplied in the quantities at which consumers' willingness to pay equalled producers' willingness to supply. By contrast, a number of commodities can be termed 'recommended' (Figure 1b) in the sense that the authorities tried to have the households consume them rather than 'rationed' goods. Typical 'rationed' goods were foodstuffs that had to be imported, while 'recommended' goods could be produced with domestic resources that were of no strategic importance for armaments production.

The curves in bold lines indicate the situation in early 1933 when, after three consecutive years of deflation, low prices $\left(\mathrm{p}^{*}\right)$ cleared the markets. In subsequent years, employment increased, which shifts the demand curve to the right (shift A in Figures 1a and 1b). Right from the beginning the government tried to persuade consumers to substitute 'recommended' goods like rye bread, potatoes, fish, apples, sugar, jam and rayon textiles for 'rationed' goods like white bread, meat, animal fat, tropical fruits or cotton textiles. ${ }^{20}$ In other words, these measures targeted consumer preferences (shift B). Less subtle government action incurred surplus costs for producers (shift C). E.g., a quite bizarre restriction was the enforced intermixture of (dear) butter into (cheap) margarine. This made margarine dearer and less attractive for less affluent consumers. It also affected the supply of butter, itself a rather scarce good, but it helped reduce the import demand of the margarine mills for sun flower oil, thereby saving scarce foreign exchange. Another grotesque example is the setup of a national whaling fleet that was to deliver the input for train oil, another substitute for sun flower oil. ${ }^{21}$ Even more interventionist measures were direct restrictions on the purchase of input goods, on imports and even on plant investment. Most of these measures have already been described in the 1940s in the seminal works of Otto Nathan, Milton Fried and Samuel Lurié. ${ }^{22}$ A

19 While the average savings-income ratio for the period 1926-29 was 7.0 per cent, the annual figures for 1933-38 are 2.5, 5.0, 5.6, 4.2, 5.4 and 8.2, respectively. Savings (excluding those of foreigners) taken from Deutsche Bundesbank, Geld- und Bankwesen in Zahlen 1876-1975, Frankfurt a.M. 1976, p. 4, disposable income from Spoerer, Demontage, pp. 436-438. In the sources, income data for 1938 include Austria, savings data not. The figure for disposable income in 1938 has thus been transformed to pre-1938 territory by the net national income data in: Statistisches Jahrbuch für das Deutsche Reich (1941-42), pp. 604-605, which are given for both pre-1938 and 1938 territory.

20 Cf. H. Berghoff, Enticement and Deprivation: The Regulation of Consumption in Pre-War Nazi Germany, in M. Daunton/M. Hilton (Eds.), The Politics of Consumption. Material Culture and Citizenship in Europe and America, Oxford 2001, pp. 165-184, here p. 173; Idem, "Times Change and We Change with Them". The German Advertising Industry in the Third Reich: Between Professional Self-Interest and Political Repression, in: Business History 45, 2003, pp. 128-147.

21 Cf. B. Pelzer/R. Reith, Margarine. Die Karriere der Kunstbutter, Berlin 2001, pp. 88-89; R. Reith, "Hurrah, die Butter ist alle!". "Fettlücke" und "Eiweißlücke" im Dritten Reich, in: M. Pammer/H. Neiß/M. John (Eds.), Erfahrung der Moderne, Stuttgart 2007, pp. 403-426; O. Sparenberg, ,Segen des Meeres“: Hochseefischerei und Walfang im Rahmen der nationalsozialistischen Autarkiepolitik, Berlin 2012.

22 Cf. Nathan/Fried, Economic System; Lurié, Private Investment. 
more detailed look on the textile industry has recently been provided by Gerd Höschle. ${ }^{23}$ These restrictions result in a kinked supply curve (shift D). In contrast, the supply of 'recommended goods' was fostered by subsidies (shift E). On the aggregate, restrictive policies by far outweighed supportive measures.

Figure 1a: Policy measures to restrict the consumption of a 'rationed' good

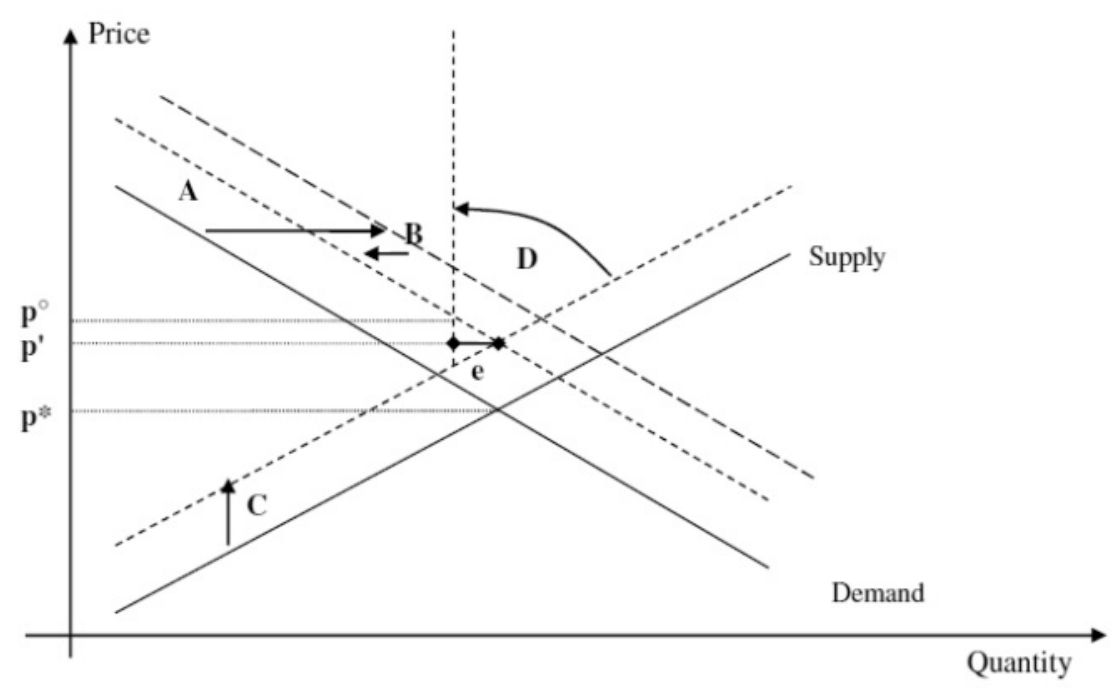

Figure 1b: Policy measures to encourage the consumption of a 'recommended' good

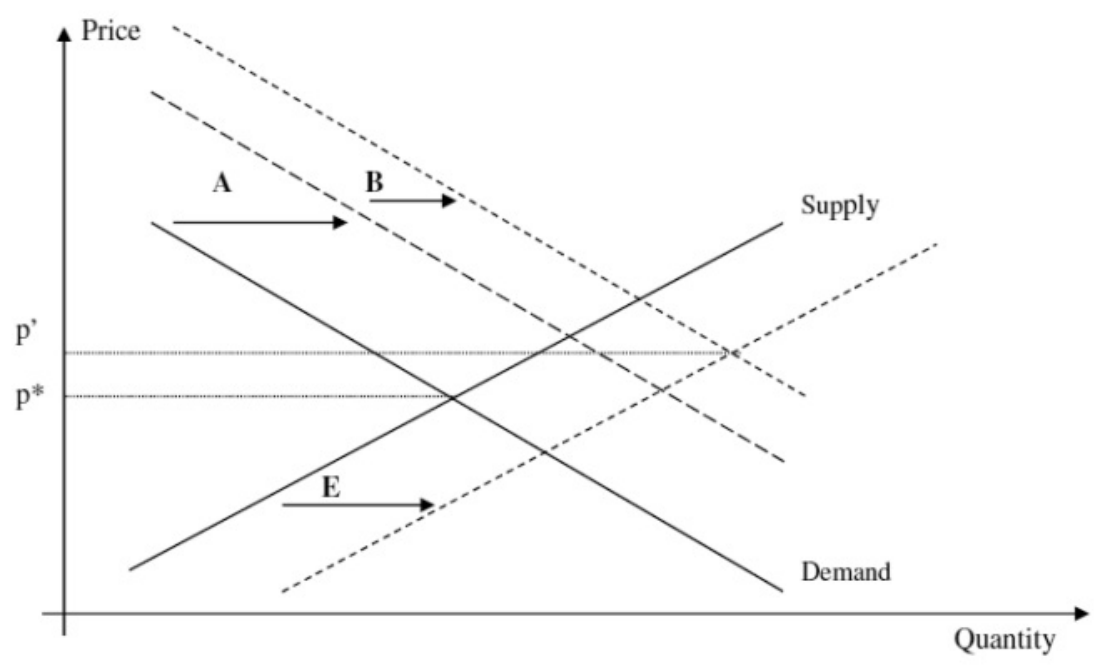

23 Cf. G. Höschle, Die deutsche Textilindustrie zwischen 1933 und 1939. Staatsinterventionismus und ökonomische Rationalität, Stuttgart 2004. 
Had the regime stopped here, the combination of increased demand and curtailed supply on the markets for 'rationed' goods would inevitably have resulted in price increases. Indeed, the prices of many consumer products showed upward trends. Hence the Nazis tightened existing price control measures which had been introduced by preceding governments. The story of Nazi price policies is very complicated as a number of conflicting aims had to be reconciled. The most notable aims were, on the one hand, the political imperative to keep prices stable and, on the other hand, the ambition to increase farmers' incomes, which had suffered in the years of deflation. In a series of articles, André Steiner has traced the history of price controls in the 1930 s. $^{24}$

The picture which emerges from these policies is quite clear. 'Rationed' good markets were characterised by controlled prices $\left(\mathrm{p}^{\prime}\right)$ below market clearing levels $\left(\mathrm{p}^{\circ}\right)$. Since prices were bereft of their allocation function, queuing and black markets reduced the excess demand (e) and solved the allocation problem - the Nazis still shied away from officially rationing consumer goods and this was not introduced before late August 1939, a few days before the raid on Poland.

While the intense historical research of the past decades has succeeded in describing the policies that affected the production and consumption of consumer goods, the analysis of the actual effects on the standard of living has remained underdeveloped. A seminal paper on the biological standard of living by Jörg Baten and Andrea Wagner made a start, finding that several demographic indicators were quite unfavourable to Nazi Germany compared to their Western neighbours. Moreover, regional shortages of protein supply correlated with increases in infant mortality. ${ }^{25}$ In line with these findings, we believe that the degree of failure of German consumption policies in Nazi Germany has so far been underestimated. We ask to what extent German households were forced to deviate from the consumption bundle they would have preferred in a less regulated economy.

\section{The Impact of Nazi Policies on Food Consumption}

To what extent did the Nazis' inability to modernise and increase agricultural production, the unwillingness to import foodstuffs, the imposition of supply constraints and political prices affect private food consumption? It should be emphasised that in German households of the interwar period food expenses still dominated all other expenditure issues.

In general, we suppose that, when real GDP and disposable income per capita are increasing, households voluntarily substitute high-valued foodstuffs with relatively high income elasticity for basic food stuffs with relatively low income elasticity. Any analysis of consumption after 1933, however, is confronted with the problem that it was distorted by the

24 Cf. A. Steiner, Von der Preisüberwachung zur staatlichen Preisbildung. Verbraucherpreispolitik und ihre Konsequenzen für den Lebensstandard unter dem Nationalsozialismus in der Vorkriegszeit, in: Idem $(E d$.$) , Preispolitik und Lebensstandard. Nationalsozialismus, DDR und Bundesrepublik im Vergleich,$ Cologne 2006, pp. 23-85; Idem, Der Brotpreis - ein politischer Preis unter den Bedingungen des NSRegimes, in J. Bähr/R. Banken (Eds.), Wirtschaftssteuerung durch Recht im Nationalsozialismus. Studien zur Entwicklung des Wirtschaftsrechts im Interventionsstaat des "Dritten Reichs", Frankfurt a.M. 2006, pp. 365-420. For price policies in public procurement cf. J. Streb, Negotiating Contract Types and Contract Clauses in the German Construction Industry during the Third Reich, in: RAND Journal of Economics 40, 2009, pp. 364-379.

25 Cf. Baten and Wagner, Autarchy. 
government measures discussed in section two. The multitude of constraints imposed on the household's consumption behaviour must have led to numerous involuntary substitution effects. The problem is how to assess changes in the food consumption bundle in a world in which price signals do no longer convey valid information on how much households value the goods they consume.

Table 1: $\quad$ Expenditure Shares of Various Household Types, 1927-28 (per cent)

\begin{tabular}{|l|c|c|c|c|}
\hline Household type, annual income & Food & Habitation & Clothing & Other \\
\hline Blue collar & & & & \\
$<2,500 \mathrm{RM}$ & 48 & 19 & 10 & 23 \\
$>$ 4,300 RM & 42 & 17 & 5 & 36 \\
\hline White collar & & & & \\
< 3,000 RM & 42 & 22 & 11 & 25 \\
$>$ >, $100 \mathrm{RM}$ & 28 & 21 & 13 & 38 \\
\hline Civil servants & & & & \\
$<3,000 \mathrm{RM}$ & 43 & 22 & 12 & 23 \\
$>10,000 \mathrm{RM}$ & 22 & 24 & 12 & 42 \\
\hline
\end{tabular}

Source: Statistisches Reichsamt, Die Lebenshaltung von 2000 Arbeiter-, Angestellten und Beamtenhaushaltungen. Erhebungen von Wirtschaftsrechnungen im Deutschen Reich von 1927/28, Vol. I, Berlin 1932, pp. 20, 32, 43.

To solve this problem we make use of a straightforward benchmark that gives us an idea about how consumption would have roughly developed in the absence of Nazi market regulation. Assuming both that the preferences of the German consumers were stable in the mid20th century and that preferences in West Germany were not substantially different from those of the whole of Germany, the actual consumption pattern of Germany in the 1950s should mirror the hypothetical unconstrained consumption of the 1930s.

In Table 2 we compare the average per capita food consumption of the calendar years 1927-28 (=100) with that of 1937-38 and the average of the harvest years 1950-51 and 195152. The years 1927-28 and 1937-38 are chosen because they were the peak years of the business cycles in the Weimar Republic and the Third Reich, respectively. In 1951, disposable income of private households, which is the best indicator for their consumption potential, equalled the respective number of 1937-38 (per capita and in constant prices). ${ }^{26}$ The decisive difference between the years 1937-38 and 1951 is that demand and supply of foodstuffs was subjected to substantial regulation in the late 1930s, but much less in the early 1950s. In 1951, when real disposable income per capita was 13 per cent higher than in 1927-28, German

26 In constant prices which is not unproblematic as the cost of living index was, of course, influenced by Nazi price policies. By comparing prices from household surveys that were actually paid with the official prices, however, Steiner has argued that price differences were negligible in the food sector; cf. A. Steiner, Zur Neuschätzung des Lebenshaltungskostenindex für die Vorkriegszeit des Nationalsozialismus, in: JWG 2005/2, pp. 129-152. 
Table 2: $\quad$ Real Disposable Income per Capita and per Capita Food Consumption in Germany, 1927-28=100

\begin{tabular}{|l|c|c|c|}
\hline \multicolumn{1}{|c|}{ Year } & $\begin{array}{c}\text { Third Reich } \\
\varnothing 1937-38\end{array}$ & $\begin{array}{c}\text { Federal Republic } \\
\text { (i) }\end{array}$ & $\begin{array}{c}\text { (i) in per cent of (ii) } \\
\text { (ii) }\end{array}$ \\
\hline Real income per capita & 112 & 113 & 99 \\
\hline Skimmed milk & 308 & 195 & 158 \\
Fresh fruits & 98 & 145 & 68 \\
Margarine & 85 & 139 & 62 \\
Tropical fruits & 77 & 128 & 61 \\
Sugar & 104 & 114 & 91 \\
Wheat flour products & 90 & 108 & 84 \\
Eggs & 111 & 103 & 108 \\
Potatoes & 102 & 99 & 99 \\
Total fat & 96 & 97 & 95 \\
Full-cream milk & 92 & 97 & 99 \\
Vegetables & 93 & 93 & 138 \\
Beef & 107 & 77 & 161 \\
Butter & 122 & 76 & 145 \\
Total meat & 106 & 73 & 144 \\
Pork & 104 & 72 & 161 \\
Rye flour products & 105 & 65 & \\
\hline
\end{tabular}

Notes: 1927-28: Germany without Saarland; 1937-38: Germany with Saarland and without Austria; 1951: Federal Republic of Germany with Berlin (West) and without Saarland.

Sources: Consumption: D. Grupe, Die Nahrungsmittelversorgung Deutschlands seit 1925. Eine Auswertung der einschlägigen Statistiken zu vergleichbaren Versorgungsbilanzen, Hanover 1957, pp. II.88f. Prices: Statistisches Jahrbuch für das Deutsche Reich (1933), p. 251, (1935), p. 271; Vierteljahrshefte zur Statistik des Deutschen Reichs (1938), p. II.140, (1940), p. II.80; Statistisches Handbuch für Deutschland (1949), p. 467. Disposable income: calculated for the interwar period from A. Ritschl, Deutschlands Krise und Konjunktur 1924-1934. Binnenkonjunktur, Auslandsverschuldung und Reparationsproblem zwischen Dawes-Plan und Transfersperre, Berlin 2002, Tables A12, B1, B2 and B5, and W. G. Hoffmann/J. H. Müller, Das deutsche Volkseinkommen 1851-1957, Tübingen 1959, pp. 43, 47, 49, 54; for 1950-55 cf. Statistisches Jahrbuch für die Bundesrepublik Deutschland (1953), p. 451, (1956), pp. 377, 398, (1954), p. 403, (1957), p. 418, and (1958), p. 481.

households substituted wheat flour for rye flour and potatoes, and fresh and tropical fruits for vegetables. They also substituted margarine for butter which reflects a preference for a cheap fat spread (the role of cholesterols was not yet known). Under the assumption of stable preferences, it is reasonable to expect that German households would have liked to consume a similar bundle of foodstuffs in the boom years of the Third Reich when real disposable income per capita was as high as in 1951. In Table 3 we have sorted the foodstuffs by the 
increase of their consumption between 1951 and 1927-28, the benchmark year (col. ii). The Table demonstrates that, despite the identical level of real disposable income per capita, the consumption pattern in 1937-38 differed considerably from the one in the Federal Republic (col. iii). Per capita consumption of typical inferior goods like rye flour products and potatoes was higher, while per capita consumption of wheat flour products, fresh fruits, tropical fruits, sugar, margarine, full-cream milk and vegetables was lower than after the Second World War.

The demand patterns for certain products need a little more explanation. As the German margarine industry relied on imported primary products, the Nazi government severely constrained margarine production and subsidised butter production. In addition to the intermixture of butter into margarine, margarine producers were also forced to substitute skimmed milk for vegetable oils. ${ }^{27}$ As margarine production decreased consumers were forced to buy the dearer butter. Another rather income-elastic product which was consumed in larger quantities in 1937-38 than in 1927-28 and 1951 is meat. ${ }^{28}$

Yet, apart from these cases it is clear that rye bread and potatoes were a much more frugal diet than white bread, vegetables and fruits. Obviously, as a result of the regulation of agricultural production, food processing and foreign trade, German households were forced to spend their income mainly on foodstuffs they preferred less. If, however, the German consumers were forced to substitute rye products for wheat products, were they compensated by more meat and butter, and even better off in the end? An obvious further step of our analysis is to weight these countervailing effects.

From a large consumer survey carried out by the German statistical office we know the average quantities of the most important foodstuffs consumed by a typical worker household in 1927-28. As the statistical office also recorded the average prices for the most important foodstuffs, we are able to calculate the value of the average food consumption bundle in 1927-28, which is 863 RM per year. ${ }^{29}$ After the trough of the economic crisis in the early 1930s, real disposable income per capita attained the level of 1927-28 in 1935-36. If we value the actual food consumption bundle of 1935-36 in prices of 1927-28, we derive 859 RM. What is interesting here is not so much that the value of the 1935-36 food consumption bundle was slightly below the budget constraint of 1927-28 but that the household would have been able to buy the 1935-36 bundle already in 1927-28, yet obviously preferred another one: white bread rather than rye bread, beef rather than pork, fruits and vegetables rather than potatoes. In other words, the following Table 3 illustrates the effects of involuntary substitution.

27 Cf. Pelzer/Reith, Margarine, pp. 76-77.

28 For the consumption of meat in a long-term perspective cf. H.-J. Teuteberg, Der Fleisch- und Wurstverzehr der Deutschen in historischer Betrachtung, in: Ernährungsforschung, 1998, pp. 1-28. Meat consumption in the early 1950s was probably still restrained by the depletion of cattle stocks during the war.

29 Compatible consumption and price data are available for the following foodstuffs, ordered in the rough amount of quantities consumed by a typical household: Potatoes, full-cream milk, rye flour products, wheat flour products, sugar, margarine, eggs, pork, butter, beef, rice, peas, veal and mutton. As households also consumed other food products, the amount of $863 \mathrm{RM}$ underestimates the value of the full bundle actually consumed. 
Table 3: $\quad$ Involuntary Substitution: Real Disposable Income per Capita and per Capita Food Consumption in Germany, $1935-36$ vs. 1927-28 change in per cent)

\begin{tabular}{|l|c|}
\hline Year & $\varnothing 1935-36$ \\
\hline Real income per capita & -1 \\
\hline Skimmed milk & +168 \\
Butter & +13 \\
Rye flour products & +5 \\
Pork & +3 \\
Potatoes & +1 \\
Total meat & \pm 0 \\
Eggs & \pm 0 \\
Sugar & -1 \\
Vegetables & -5 \\
Total fat & -5 \\
Full-cream milk & -8 \\
Fresh fruits & -8 \\
Margarine & -8 \\
Tropical fruits & -9 \\
Wheat flour products & -9 \\
Beef & -9 \\
\hline
\end{tabular}

Notes: 1927-28: Germany without Saarland; 1937-38: Germany with Saarland and without Austria.

Sources: Grupe, Nahrungsmittelversorgung, pp. II.88f.

If we repeat the same procedure for the 1937-38 food consumption bundle, we derive a value of 884 RM in 1927-28 prices. The question whether or not households preferred this slightly dearer 1937-38 consumption bundle to the 1927-28 bundle can no longer be answered with the help of the theory of revealed preferences. ${ }^{30}$ Figure 2 illustrates that both cases - an increase or a decrease of the utility from food consumption - are possible. The fact that the bundle actually consumed in 1937-38 valued by prices of 1927-28 was 2.5 percent more expensive than the 1927-28 bundle does not automatically imply that the former was preferred to the latter. Figure 2 demonstrates this graphically for a simplified world of just two commodities.

Ignoring the tiny difference of 4 RM we can say that the 1927-28 and 1935-36 consumption bundles are on the same budget line. From the theory of revealed preferences we can infer that the 1927-28 bundle must have been preferred by the consumers of the late 1920s to that of 1935-36, as they could have afforded this latter bundle as well. Assuming constant preferences we can then conclude that the consumers of the year 1935-1936 would also have preferred the 1927-28 bundle. In order to assess the valuation of the 1937-38 bundle, which

30 For the theory of revealed preferences cf. A. Mas-Colell/M.D. Whinstin/J.R. Green, Microeconomic Theory, Oxford 1995, pp. 28-36. 
is situated at a slightly higher budget line, we would need detailed information about the preference ordering (which shape the indifference curve ${ }^{31}$ ) but which are not available. Given the distortionary effects of the Nazi supply and demand policies in the 1930s we are tempted to assume that the 1937-38 bundle was located below the indifference curve and therefore still inferior to that of 1927-28, but without knowledge of the preferences this remains speculation.

Figure 2: $\quad$ Food consumption bundles of 1927-28, 1935-36 and 1937-38 valued by prices of $1927-28$

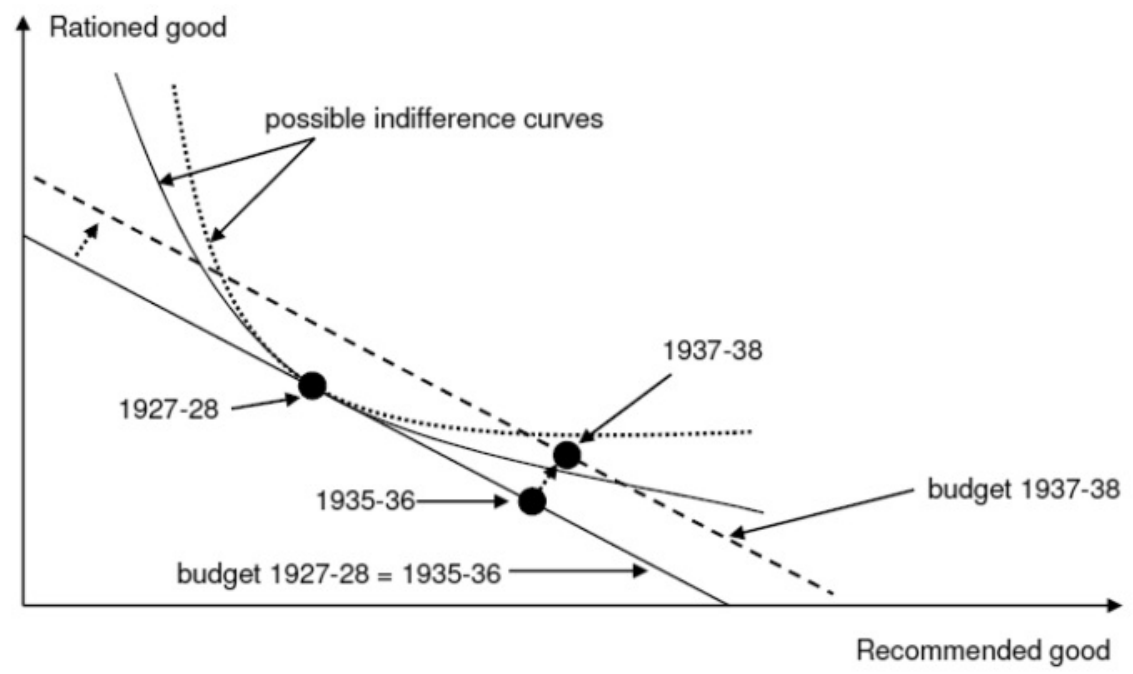

A possible objection that we cannot test here is that the regime might have compensated consumers for their frugal diet with non-food products such as cloths or better housing. However, the complaints about the deteriorating quality of cloths were ubiquitous, and quality deterioration was also a problem in residential construction. ${ }^{32}$

We can conclude that, on the eve of World War II, the diet of German consumers was at most at the pre-crisis level of the late 1920s. Although American-style mass consumption was on the agenda of the regime, ${ }^{33}$ it failed to improve the standard of living compared to 1927-28.

\section{Concluding Remarks}

The evidence presented here supports the more pessimistic view of the standard of living under Nazi rule. In passing we note that the antithesis of "butter" vs. "guns" that has occupied the literature on the Nazi economic system since at least the 1940s does not make much sense. "Butter" is not a suitable metaphor for the consumer demand of the 1930s as it was more of a 'recommended' product in the sense of Figure $1 \mathrm{~b}$ than a 'rationed' product. Of course most

31 In microeconomic consumer theory, the indifference curve shows all consumption bundles that a household has an equal preference for. Below the indifference curve we find all consumption bundles a household prefers less than those bundles placed at the indifference curve.

32 Cf. Berghoff, Enticement, pp. 175, 180-181.

33 Cf. Berghoff, Enticement. 
German consumers would have preferred butter to margarine if money were no matter. But given that butter was more than twice as expensive as margarine most consumers wanted to buy margarine for their everyday sandwiches. Dear butter was a product that many households would have liked to replace with cheap margarine and thus is much more a metaphor for consumption enforced by the regime. The challenge was to supply more margarine, not more butter.

A more important issue is the question of approval of the regime. If, as we hope to have shown, the material standard of living was very modest and if, as Baten and Wagner argue, the biological standard of living fell behind that of Western Europe, why were most Germans in favour of the regime? Recent economic research on happiness and satisfaction might help. ${ }^{34}$ As Bruno Frey and Alois Stutzer point out, however, important variables that are conducive for happiness, apart from material affluence, are political, economic and personal freedom, direct political participation and decentralisation, ${ }^{35}$ issues not very prominent in Nazi Germany.

And probably not among the German people. As shown in the introduction, it has always been debated among economic historians whether the peak of the 1920s upturn or the traumatic experience of 1931-32 was the reference period for the contemporaries. Hartmut Berghoff has argued that 1932 served as reference period not only for the Nazi propaganda, but for most German households as well. According to Berghoff, another factor contributed to the approval of the regime, even among working class people. Nazi propaganda was quite successful in delivering 'virtual consumption', which served as a substitute for real (and restrained) consumption. ${ }^{36}$

In our understanding, 'virtual consumption' might be interpreted in two ways. On the one hand, the notion suggests that the Nazis were successful in having consumers defer (material) consumption to a future date, e.g. by participating in the Volkswagen savings program of the Kraft durch Freude organisation which started in August 1938. At least the more affluent strata of the German society may have dreamt that these consumption promises would materialise in future and were in the position to increase their propensity to save. This might be a reason (among others) why the savings-income ratio, which was remarkably low throughout the mid-1930s, increased in $1938 .{ }^{37}$ For lower class households, probably even for the median household, most Volks-products were illusionary, ${ }^{38}$ as too was the likelihood of participating in the much celebrated cruises organized by Kraft durch Freude. The budget of lower class households was spent on food, rent and clothing and thus for product groups in which the national socialist regime had a remarkably modest record.

On the other hand, 'virtual consumption' may stand for an increase in the consumption of public goods which seemingly compensated many households for the mediocre consumption

34 Cf. F. Wahl, Die Entwicklung des Lebensstandards im Dritten Reich. Eine glücksökonomische Perspektive, in: JWG 2013/1 (this issue).

35 Cf. B. Frey/A. Stutzer, What Can Economists Learn from Happiness Research?, in: Journal of Economic Literature 40, 2002, pp. 402-435; Idem, Happiness Research: State and Prospects, in: Review of Social Economy 63, 2005, pp. 207-228.

36 Cf. Berghoff, Enticement, p. 173; Idem, Neue Kontroversen zur Konsumgeschichte des Nationalsozialismus, in: Geschichte in Wissenschaft und Unterricht 58, 2007, pp. 502-518, here pp. 509, 518.

37 See fn. 19 below.

38 Cf. W. König, Volkswagen, Volksempfänger, Volksgemeinschaft: "Volksprodukte" im Dritten Reich. Vom Scheitern einer nationalsozialistischen Konsumgesellschaft, Paderborn 2004, pp. 258-262. 
possibilities of private goods and the loss of human rights. To the list of non-economic variables that Frey and Stutzer find important for individual happiness one could add, at least for Germany in the 1930s, public goods like national pride (re-militarisation of the Rhineland and the Olympic Games 1936), economic and (for unpolitical and 'aryan' citizens) political stability. In particular, economic stability may have played a very important role after the shocking experiences of the 1923 hyperinflation and the great slump of 1931 and 1932. The frustrating answer of why so many Germans supported the Nazi regime may simply be that German households were willing to trade utility from material consumption and human rights for lower socioeconomic risks and national pride.

\section{Mark Spoerer and Jochen Streb: Guns and Butter - But No Margarine: The Impact of Nazi Economic Policies on German Food Consumption, 1933-38}

\section{Abstract}

The German population's material standard of living during the 'peace years' of the Nazi regime (193338) is much debated. We use hitherto disregarded consumption data and the axiom of revealed preferences to test whether the material standard of living improved. We find that the food consumption bundle realized in 1935-36 must have been inferior to that of 1927-28, despite GDP per capita being much higher. Even in 1937-38 consumers were probably worse off compared to 1927-28. We conclude that increasing consumption constraints forced German consumers to diet and thus to a material standard of living that was much more frugal than national income figures suggest.

Keywords: consumption; revealed preferences; Third Reich

JEL-Codes: N 34, D 12, P 46

Mark Spoerer is professor of economic and social history at the University of Regensburg. His research topics include German economic and business history of the 19th and 20th centuries, forced labour in the two world wars and European agricultural policies in the 20th century. Among his most recent publications are: "Fortress Europe" in Long-term Perspective: Agricultural Protection in the European Union, 1956-2003. In: Journal of European Integration History (2010); The Evolution of Public Finances in Nineteenth-Century Germany. In: J.Cardoso/P. Lains (eds.), Paying for the Liberal State, Cambridge 2010 and The imposed gift of Versailles: the fiscal effects of restricting the size of Germany's armed forces, 1924-9. In: Economic History Review (2010, joint with Max Hantke).

Jochen Streb is the Professor of Economic History in the Department of Economics at the University of Mannheim. Streb's research focuses on the innovation history and regulation history of Germany in the nineteenth and twentieth century. He has published in the Economic History Review, Explorations in Economic History, the Journal of Economic History, The RAND Journal of Economics, Research Policy, and other journals.

Prof. Dr. Mark Spoerer

Universität Regensburg

Lehrstuhl für Wirtschafts- und Sozialgeschichte

D-93040 Regensburg

mark.spoerer@ur.de
Prof. Dr. Jochen Streb

Universität Mannheim

Abteilung Volkswirtschaftslehre

Lehrstuhl für Wirtschaftsgeschichte

L7,3-5

D-68131 Mannheim

streb@uni-mannheim.de 